\title{
Recovering the jaguar Panthera onca in peripheral range: a challenge to conservation policy
}

Tony POVILITIS

\begin{abstract}
The recovery goal for the jaguar Panthera onca in the USA should be to restore significant presence with some reproduction, consistent with historical records. Nevertheless, the prevailing conservation strategy for the jaguar does not include restoration in peripheral range and merely seeks long-term survival of the jaguar within its existing northern range, which is almost entirely in Mexico. Broader issues are whether recovery programmes should include peripheral populations, range expansion and species representation across ecoregions. Considering jaguar history, habitat, population requirements, wildlife management and other factors in the southwestern USA, efforts to re-establish the species would have a reasonable chance of success. Recovery of the jaguar in the USA would improve prospects for the adaptation and survival of the species within its northern range, given habitat loss, conflicts with humans and climate change.
\end{abstract}

Keywords Conservation policy, jaguar, Panthera onca, peripheral range, species recovery

\section{Introduction}

Tn 2010 the U.S. Fish and Wildlife Service (USFWS) decided to prepare a recovery plan for the jaguar Panthera onca, which historically occurred in the southern USA (Fig. 1), at the northern edge of its global range. The jaguar is endangered in the USA and categorized as Near Threatened on the IUCN Red List (Caso et al., 2008; USFWS, 2012a). However, the agency has subsequently focused not on jaguar recovery in the USA but rather on sustaining the species within its broader northern range, which is almost entirely in Mexico (USFWS, 2012a). The USFWS regards species conservation fundamentally as the avoidance of global extinction and defines a 'significant portion of a species range' for conservation as one without which the entire species would be at risk of extinction (Carroll et al., 2010; USFWS \& NOAA, 2011). In its view, only a large portion of the jaguar's northern range meets that requirement.

Tony Povilitis Life Net Nature, South Bascom Trail, Willcox, Arizona 85643, USA. E-mail tpovilitis@lifenetnature.org

Received 18 May 2013. Revision requested 23 July 2013.

Accepted 9 September 2013. First published online 14 February 2014.
I advocate for a recovery plan to restore the jaguar to its former range in the south-west USA (Arizona and New Mexico) as part of an expanded binational effort to conserve the northernmost jaguar population, now restricted mainly to neighbouring Sonora, Mexico. Vertebrate population segments merit conservation when they occur in a unique ecological setting for the species or are separated from other populations by physical, ecological or other factors, including differences between countries in terms of wildlife law enforcement, habitat management and regulatory mechanisms (USFWS \& NMFS, 1996). As I propose here, a recovery plan for the Southwest would draw on knowledge of historical presence of jaguars, conservation requirements in adjacent Mexico, regional habitat features and corridors, and programmes elsewhere to re-establish large carnivores and promote their coexistence with people.

\section{Historical occurrence in the Southwest}

Historical accounts of jaguars in Arizona and New Mexico for 1900-1998 include 71 adult animals reported dead (or in two cases photographed), including 16 males, 9 females and 46 of uncertain sex. Brown \& López-González (2001) listed 61 of these records and Grigione et al. (2007) tallied seven mortalities in Arizona that appear distinct, including a female with young cited by Hoffmeister (1986). Robinson (2006) found records of two additional kills in New Mexico. Fisher \& Bell (1927) referenced two female jaguars among at least five jaguars killed in Arizona in the mid 1920s, at least one of which appears different from jaguars reported by later authors. Around or just prior to 1900 more than four jaguars were reported killed in Arizona, including a female with young in the Grand Canyon (Lange, 1960).

Of eight adult female jaguars accounted for by Brown \& López-González (2001) and Hoffmeister (1986), four occurred in southern and three in northern Arizona. Three of the females had cubs, with two of these groups occurring in northern Arizona. Applying the percentage of females among jaguars of known sex (36\%, 25 records) to the number of animals of unknown sex (46 records), 17 additional females were probably among reported kills during the past century.

Apart from accounts with physical evidence, Lange (1960) and Grigione et al. (2007) tallied 15 sightings of jaguar in Arizona for 1900-1998, including reports of a female and two cubs in the Grand Canyon (Hoffmeister, 1986) that may 


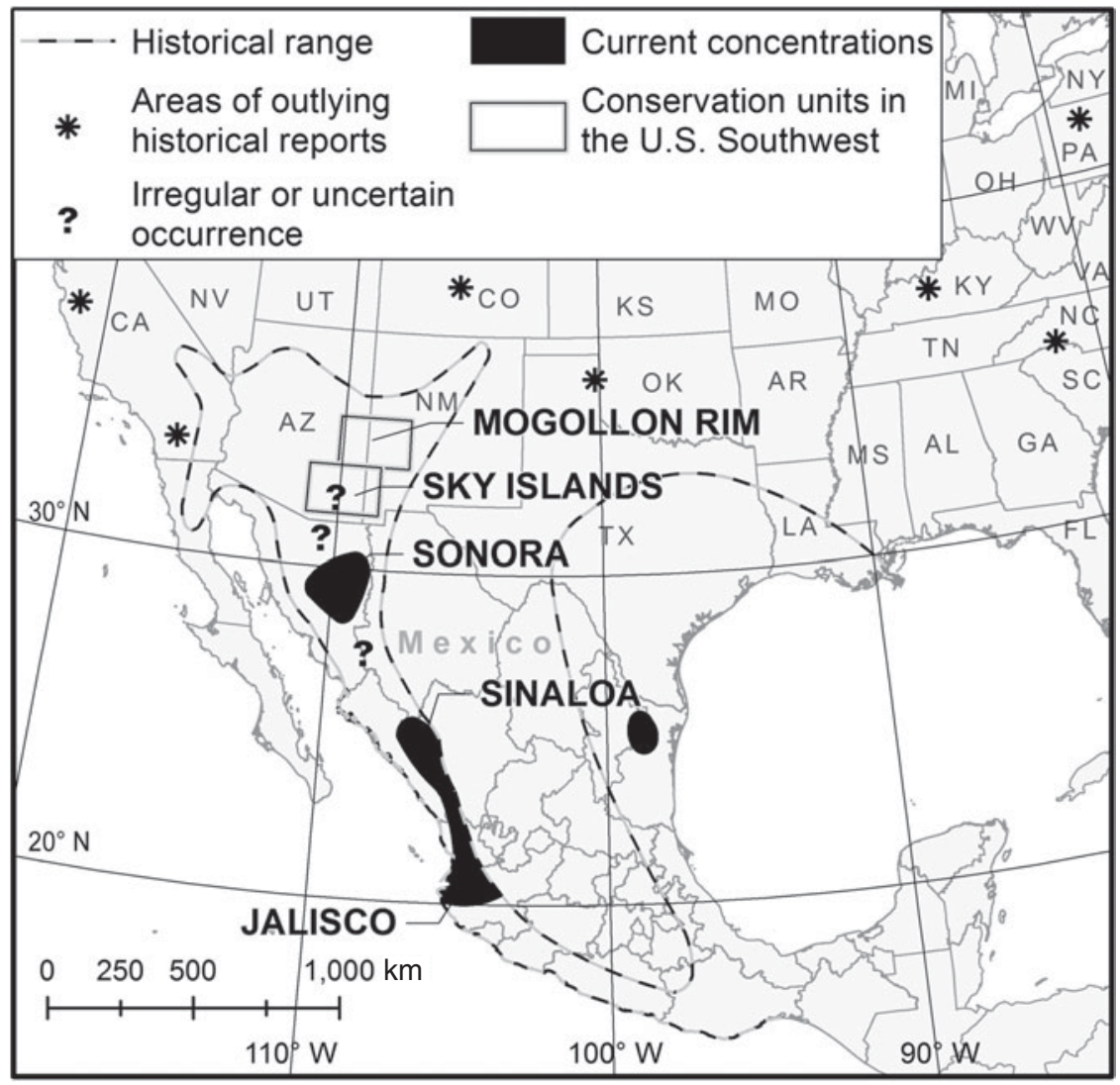

FIG. 1 Historical and current distribution of the northern jaguar Panthera onca (based on Rafinesque, 1832; Matthiesen, 1959; Daggett \& Henning, 1974; Hall, 1981; Navarro-Serment et al., 2005; Robinson, 2006; Zeller, 2007; Grigione et al., 2009; Judd, 2009; Mahler, 2009). have been subsequently killed. For New Mexico, Robinson (2006) included eight additional observational records for that time period. Native Americans reported jaguars in these states and neighbouring California (Daggett \& Henning, 1974; Mahler, 2009). Hall (1981) delineated the jaguar's historical range to include portions of Arizona and New Mexico, as well as California, Texas and Louisiana (Fig. 1).

Since the late 1990s 5-6 individual jaguars have been recorded in the Southwest (USFWS, 2012a), one by remote cameras over a 12-year period (McCain \& Childs, 2008). These jaguars appeared to originate in the neighbouring state of Sonora, Mexico, where a concentration of jaguars occurs c. $220 \mathrm{~km}$ south of the USA (LópezGonzález, 2004).

The distributional pattern and decline of jaguar records in the Southwest provides strong evidence for a historical population of the jaguar. Kill records for 1900-1980, when plotted at 10-year intervals, showed a decrease characteristic of an overexploited resident population (Brown, 1983). Hunting, trapping and poisoning (Brown \& López-González, 2001) were primary factors in the extirpation of the jaguar from most of the Southwest, beginning with bounties on the animal imposed by Spanish authorities (Matthiessen, 1959).

\section{The northern jaguar population}

Estimates of jaguar numbers in Sonora, Mexico, are 50-271 (USFWS, 2012a). Jaguars there face heavy human-induced mortality (Rosas-Rosas, 2006), and the effect of hunting on prey is also of concern (Brown \& López-González, 2001). Zeller (2007) estimated that only $4 \%$ of jaguar habitat in Sonora receives some protection. With poaching common throughout Mexico, jaguar numbers will decline further (Carrillo et al., 2007).

Population viability prospects for northern jaguars could improve with range expansion into the Southwest, and with sustained connectivity to a jaguar population in southern Sinaloa south to Jalisco, where the number of jaguars has been estimated to be 479->500 (USFWS, 2012a). As male jaguars are capable of long-distance dispersal, connectivity along the $400 \mathrm{~km}$ corridor between concentrations in Sonora and southern Sinaloa (Navarro-Serment et al., 2005) is plausible. However, any existing connectivity may be lost if the Sinaloa-Jalisco population, believed to be in decline (Zeller, 2007), is significantly reduced.

Estimated population sizes required for viability are generally much greater than the combined estimate of 530-800 jaguars for Sonora and Sinaloa-Jalisco. Reviews of population viability studies have found that thousands 
of individuals are generally needed for populations to withstand environmental fluctuation and catastrophic events, and to ensure continuation of evolutionary processes (Traill et al., 2010; Flather et al., 2011). Thus, the longterm prospect is not good for $<_{1,000}$ animals, especially with uncertain population stability and connectivity. For northern jaguars renewed presence in Arizona and New Mexico could improve overall population size and habitat options, genetic integrity, and the outlook for survival of the species given human-induced environmental changes range-wide (Boydston \& López-González, 2005).

\section{Habitat in the Southwest}

Jaguars in Arizona, New Mexico and Sonora historically occurred within six ecological regions not found elsewhere, with three of these unique to the USA (Hall, 1981; North American Atlas, 2006). A coarse-scale classification of geographical regions for the jaguar places the Southwest and Sonora in Mexican xeric and temperate pine-oak forest categories, with Mexican tropical dry forest prevailing further south (Sanderson et al., 2002).

At the community level the jaguar's historical range in Arizona and New Mexico encompassed 12 major biotic communities (Brown \& Lowe, 1994), half of which occur only in the USA. Records of adult jaguars killed or photographed suggest a very distinct habitat configuration for the species in the Southwest, even compared with neighbouring Sonora. Jaguars were associated with Madrean evergreen woodland (31\%), Rocky Mountain montane conifer forest (17\%), semi-desert grassland (13\%), Great Basin conifer woodland (9\%), riparian habitat (8\%) and other or uncertain biotic communities (22\%; Brown \& López-González, 2001). In contrast, specimens from Sonora were reported mostly in Sinaloan thornscrub (63\%) and deciduous forest (10\%), with fewer in Madrean evergreen woodland (5\%), Sonoran desert scrub $(5 \%)$ and other or uncertain communities $(17 \%)$. Female jaguars killed in Arizona were associated in four instances with Rocky Mountain montane conifer forest and in single instances with subalpine conifer forest, semidesert grassland and Madrean evergreen woodland (Brown \& LópezGonzález, 2001). Jaguars in the Southwest have occurred in varied topography including lowland flats, valley basins, canyons, mountains and subalpine environments (Brown \& López- González, 2001; Boydston \& López-González, 2005; McCain \& Childs, 2008).

Large portions of Arizona and New Mexico have been identified as potential jaguar habitat, based on historical occurrences, vegetation cover, topography, prey availability, proximity to surface water and other factors (Menke \& Hayes, 2003; Boydston \& López-González, 2005). Hatten et al. (2005) identified $21-30 \%$ of Arizona $\left(62,000-88,600 \mathrm{~km}^{2}\right)$ and Robinson (2006) indicated approximately half of New Mexico (c. $156,800 \mathrm{~km}^{2}$ ) as potential habitat, much of it federally-managed and protected natural resource lands.

Grigione et al. (2009) specifically identified the Sky Island and Mogollon Rim areas of the Southwest as jaguar conservation units (Fig. 1), within a broader region of jaguar habitat $\left(102,530 \mathrm{~km}^{2}\right)$ with comparable portions in the USA and northern Mexico. Federally-managed national forest lands in the Sky Island $\left(7,200 \mathrm{~km}^{2}\right)$ and Mogollon Rim $\left(17,745 \mathrm{~km}^{2}\right)$ areas could potentially support 249 jaguars, applying a density estimate of 1 jaguar per $100 \mathrm{~km}^{2}$ for Sonora, Mexico (Carrillo et al., 2007).

Potential movement corridors for the jaguar in Arizona have been identified (AWLW, 2006; Corridor Designs, 2012) and require protection, given threats to habitat connectivity, including land development and US-Mexico border fencing (USFWS, 2012b). Multi-state planning for landscape-level connectivity for wildlife is underway (WGA, 2012; WRP, 2013).

Jaguars hunt large and medium-sized animals, including common species of the Southwest (USFWS, 2012b). Large prey dominate the diet of jaguars in Sonora, including deer (Odocoileus spp.) and peccary Pecari tajacu (RosasRosas, 2006). In the Southwest ungulate populations are monitored and managed by state game authorities and are considered healthy. Post-hunt population estimates of adult white-tailed deer Odocoileus virginianus, mule deer Odocoileus hemionus and elk Alces americanus for 2009 in Arizona (exclusive of national parks and tribal lands) were 70-75,000, 75-80,000 and 30-35,000, respectively, and c. 5,000 peccaries were legally taken (AGFD, 2011). Identification of areas with prey concentrations, along with connecting habitat linkages, would guide habitat management for a newly established jaguar population.

The presence of elk in much of the jaguar's historical range in Arizona and New Mexico adds a potentially important large prey item that is absent in the south (Carrera \& Ballard, 2003). Jaguars would almost certainly kill elk, given that they often select larger prey than pumas (Laundré \& Hernández, 2010), which commonly take elk in the Southwest (Mattson et al., 2007).

Surface water is widely available for jaguar in the Southwest, most notably in mountainous terrain (Hatten et al., 2005). Widespread creation of artificial water sources, such as livestock ponds and troughs, may offset losses of some perennial sources as a result of excessive withdrawal of groundwater and livestock overgrazing.

The risk of jaguar poaching in the USA appears minimal, especially since the species received federal protection in 1997 (USFWS, 2012a). Jaguar poaching has not been reported since 1986 and Arizona and New Mexico have active anti-poaching programmes that include law enforcement and rewards to citizens for information on poachers. Nevertheless, to increase public interest and 
acceptance of jaguar conservation in the Southwest, outreach and education programmes have been proposed and could be implemented (AGFD \& NMDGF, 2007). Programmes to promote coexistence between people and large carnivores are ongoing elsewhere in the USA (Clark et al., 2005) and would help inform efforts to reduce livestock-related and other conflicts related to jaguar presence.

Habitat in arid areas such as the Southwest would be expected to naturally support lower jaguar densities than moist tropical areas. However, peripheral or marginal jaguar habitat (Rabinowitz, 1999) does not equate with poor habitat unable to sustain healthy, reproducing individuals. Southwestern jaguars tend to be as large as or larger than those in Mexico (Brown \& López-González, 2001) and a jaguar captured in Arizona in 2009, estimated to be $15-16$ years old, was reportedly the oldest recorded anywhere in the wild (AGFD, 2009).

The range of the jaguar in the Southwest and Mexico may dry significantly this century (Seager et al., 2007), with corresponding changes in species distributions, biotic communities and wildfire regimes (Gray, 2008). At the same time, tropical and subtropical ecoregions in South America may be particularly vulnerable to climate change and may soon face extreme conditions relative to past climate variability (Beaumont et al., 2011).

With climate change, human manipulation of presentday species ranges may be needed (Hadly \& Barnosky, 2009), including, in the case of the jaguar, expansion to higher latitudes. The availability in the Southwest of upperelevation habitats with relatively cool, moist climates could provide vital habitat for the species, especially in the event of severe or abrupt climate change.

\section{Reintroduction option}

The last female jaguar recorded in the USA was killed in 1963 , over $200 \mathrm{~km}$ north of the USA-Mexico border (Brown \& López-González, 2001). Since then, five males have been killed and four other individuals believed to be males have been photographed (Brown \& López-González, 2001; USFWS, 2012a). The pattern suggests that males, but not females, disperse into the USA from Sonora. Future presence of females in the Southwest may depend on established home ranges closer to the USA border. This is problematic given the relatively open, unprotected lands between jaguar concentrations in Sonora and the USA (Grigione et al., 2009), poaching in northern Sonora, and the significant presence of border security fencing, which is impermeable to large mammals (Abhat, 2011; USFWS, 2012a,b).

Barring natural movement of female jaguars from Sonora to the Southwest, their reintroduction should be considered. The USFWS has yet to formally evaluate this option and has no plans to reintroduce jaguar (USFWS, 2012c). Examining the feasibility of reintroducing the jaguar, Kelly \& Silver (2009) concluded that behavioural and ecological flexibility makes it amenable to reintroduction, and that genetic constraints are minimal given that the jaguar is outbred, with no strong geographical structure (Eizirik et al., 2001). For the Southwest, animals for translocation could originate from nearby Mexico and Guatemala, where jaguars represent an incompletely isolated phylgeographic group. Surplus jaguars are often captured and placed in wildlife rehabilitation centres and zoos (Kelly \& Silver, 2009). Jaguars likely to disperse from protected areas or subject to high risk of human-caused mortality along reserve boundaries or in habitat fragments may also be available for translocation without compromising core populations.

Translocation of female jaguars into the Southwest would be a complex and challenging undertaking but one that could draw on prior experience of establishing wild felids in the USA (Onorato et al., 2010; CDOW, 2013) and elsewhere (Hayward \& Somers, 2009).

\section{Conservation policy}

Should a nation embark on wildlife restoration in areas peripheral to core populations occurring beyond its borders? Biologists generally promote conservation of peripheral populations (Lesica \& Allendorf, 1995; Nielsen et al., 2001; Vucetich \& Waite, 2003; Gibson et al., 2009). Such populations may survive as well as or better than those in core range, depending upon the geography of human impacts (Abbitt et al., 2000; Channell \& Lomolino, 2000) and the strength of local recovery efforts. Considerations addressed here include habitat features, ecological distinctiveness of peripheral range, ability to control threats (such as poaching and habitat fragmentation), and significance of restoration to the nearest core population.

The reluctance to undertake a recovery programme for the jaguar in the USA suggests overemphasis on its nearly extirpated status, general scepticism about habitat suitability (Rabinowitz, 1999), political aversion to large carnivore restoration (Povilitis \& Becker, 2010), and the absence of peripheral range recovery in global strategies for jaguar conservation (Sanderson, et al., 2002; Rabinowitz \& Zeller, 2010). Although a temporary focus solely on existing populations may be justified for species in immediate crisis, such as the tiger Panthera tigris (Walston et al., 2010), conservation strategies limited to core areas to the exclusion of unoccupied range should be reconsidered. The concept of recovery mandates healthy, self-sustaining wildlife populations across historical ranges and ecological settings (Redford et al., 2011). 


\section{Acknowledgements}

This work was sponsored by Life Net Nature (USA), and benefited from discussions with C.D. Becker and M. Robinson. I thank the ManTech GIS Team, USA (G. Lovasz, N. Mustain, N. Look and R. Hoopes) for preparing Fig. 1.

\section{References}

Aввitt, R.J.F., Scott, J.M. \& Wilcove, D.S. (2000) The geography of vulnerability: incorporating species geography and human development patterns into conservation planning. Biological Conservation, 96, 169-175.

Авнат, D. (2011) Fenced out: wildlife impacts of the US-Mexico border fence. The Wildlife Professional, 5, 22-27.

AGfD (Arizona Game and Fish Department) (2009) Macho B Jaguar Information. Http://www.azgfd.gov/w_c/jaguar/MachoB. shtml [accessed 2 July 2012].

AGFD (Arizona Game and Fish Department) (2011) Hunt Arizona: Survey, Harvest and Hunt Data for Big and Small Game. Arizona Game and Fish Department, Phoenix, USA.

AGFD (Arizona Game and Fish Department) \& NMDGF (New Mexico Department of Game and Fish) (2007) Jaguar Conservation Framework for Arizona, New Mexico, and Northern Mexico. Arizona Game and Fish Department, Phoenix, USA.

AWLW (Arizona Wildlife Linkages Workgroup) (2006) Arizona's Wildlife Linkages Assessment. Arizona Department of Transportation, Phoenix, USA.

Beaumont, L.J., Pitman, A., Perkins, S., Zimmermann, N.E., Yoccoz, N.G. \& Thuiller, W. (2011) Impacts of climate change on the world's most exceptional ecoregions. Proceedings of the National Academy of Sciences of the United States of America, 108, 2306-2311.

Boydston, E.E. \& López-González, C.A. (2005) Sexual differentiation in the distribution potential of northern jaguars (Panthera onca). In Connecting Mountain Islands and Desert Seas: Biodiversity and Management of the Madrean Archipelago II (eds G.J. Gottfried, B.S. Gebow, L.G. Eskew \& C.B. Edminster), pp. 51-56. Rocky Mountain Research Station, Fort Collins, USA.

Brown, D.E. (1983) On the status of the jaguar in the Southwest. Southwestern Naturalist, 28, 459-460.

Brown, D.E. \& López-GonZÁlez, C.A. (2001) Borderland Jaguars: Tigres De La Frontera. University of Utah Press, Salt Lake City, USA

Brown, D.E. \& Lowe, C.H. (1994) Biotic Communities of the Southwest. University of Utah Press, Salt Lake City, USA.

Carrera, R. \& Ballard, W.B. (2003) Elk distribution in Mexico: a critical review. Wildlife Society Bulletin, 31, 272-1276.

Carrillo, L., Ceballoos, G., Chávez, C., Cornejo, J., Faller, J.C., List, R. \& ZARZA, H. (2007) Análisis de viabilidad de poblaciones y del hábitat del jaguar en México. In Conservación y manejo del jaguar en México: studios de caso y perspectivas (eds G. Ceballos, C. Chávez, R. List \& H. Zarza), pp. 187-223. Universidad Nacional Autónoma de México, Mexico City, Mexico.

Carroll, C., Vucetich, J.A., Nelson, M.P., Rohlf, D.J. \& Phillips, M.K. (2010) Geography and recovery under the U.S. Endangered Species Act. Conservation Biology, 24, 395-403.

Caso, A., Lopez-Gonzalez, C., Payan, E., Eizirik, E., De Oliveira, T., Leite-Pitman, R. et al. (2008) Panthera onca. In IUCN Red List of Threatened Species v. 2013.2. Http://www. iucnredlist.org [accessed 11 December 2013].

Channell, R. \& Lomolino, M.V. (2000) Dynamic biogeography and the conservation of endangered species. Nature, 403, 84-86.
Clark, T.W., Rutherford, M.B. \& Casey, D. (eds) (2005) Coexisting with Large Carnivores: Lessons from Greater Yellowstone. Island Press, Washington, DC, USA.

CDOW (Colorado Division of Wildlife) (2013) Success of the Colorado Division of Wildlife's Lynx Reintroduction Program. Http://wildlife.state.co.us/SiteCollectionDocuments/DOW/ Research/Mammals/ ColoradoLynxReintroductionAssessment_090710.pdf [accessed 25 July 2013].

Corridor Designs (2012) Wildlife Linkage Planning in Arizona. Http://corridordesign.org/linkages/arizona [accessed 18 July 2012].

Daggett, P.M. \& Henning, D.R. (1974) The jaguar in North America. American Antiquity, 39, 465-469.

Eizirik, E., Kim, J.H., Menotti-Raymond, M., Crawshaw, P.G., O’Brien, S.J. \& Johnson, W.E. (2001) Phylogeography, population history and conservation genetics of jaguars (Panthera onca, Mammalia, Felidae). Molecular Ecology, 10, 65-79.

Fisher, A.K. \& Bell, W.B. (1927) Report of the Committee on Economic Mammalogy. American Society of Mammalogists. Archived with the Museum of Vertebrate Zoology, University of California, Berkeley, USA.

Flather, C.H., Hayward, G.D., Beissinger, S.R. \& S Tephens, P.A. (2011) Minimum viable populations: is there a 'magic number' for conservation practitioners? Trends in Ecology \& Evolution, 26, 307-316.

Gibson, S.Y., van der Marel, R.C. \& Starzomski, B.M. (2009) Climate change and conservation of leading-edge peripheral populations. Conservation Biology, 23, 1369-1373.

Gray, G. (ed.) (2008) Scientific Assessment of the Effects of Global Change on the United States. A report of the committee on Environment and Natural Resources. National Science Technology Council. U.S. Climate Change Science Program, Washington, DC, USA.

Grigione, M.M., Menke, K., López-González, C.A., List, R., BANDA, A., CARrera, J. et al. (2009) Identifying potential conservation areas for felids in the USA and Mexico: integrating reliable knowledge across an international border. Oryx $, 43,78-86$

Grigione, M.M., Scoville, A., Scoville, G. \& Crooks, K. (2007) Neotropical cats in southeast Arizona and surrounding areas: past and present status of jaguars, ocelots and jaguarundis.

Mastozoología Neotropical, 14, 189-199.

Hadly, E.A. \& Barnosky, A.D. (2009) Vertebrate fossils and the future of conservation biology. In Conservation Paleobiology: Using the Past to Manage for the Future (eds G.P. Dietl \& K.W. Flessa), pp. 39-59. The Paleontological Society Papers No. 15. Paleontological Research Institution and its Museum of the Earth, Ithaca, USA.

Hall, E.R. (1981) The Mammals of North America. Blackburn Press, Caldwell, USA.

Hatten, J.R., Averill-Murray, A. \& Van Pelt, W.E. (2005) A spatial model of potential jaguar habitat in Arizona. The Journal of Wildlife Management, 69, 1024-1033.

Hayward, M.W. \& Somers, M.J. (eds) (2009) Reintroduction of Top-Order Predators. Wiley-Blackwell, Hoboken, USA.

Hoffmeister, D.F. (1986) Mammals of Arizona. University of Arizona Press, Tucson, USA.

Judd, R.W. (2009) The Untilled Garden: Natural History and the Spirit of Conservation in America, 1740-1840. Cambridge University Press, Cambridge, UK.

Kelly, M.J. \& Silver, S. (2009) The suitability of the jaguar (Panthera onca) for reintroduction. In Reintroduction of Top-Order Predators (eds M.W. Hayward \& M.J. Somers), pp. 187-205. WileyBlackwell, Hoboken, USA. 
Lange, K.I. (1960) The jaguar in Arizona. Transactions of the Kansas Academy of Science, 63, 96-101.

Laundré, J.W. \& Hernández, L. (2010) What we know about pumas in Latin America. In Cougar: Ecology and Conservation (eds M. Hornocker \& S. Negri), pp. 76-90. University of Chicago Press, Chicago, USA.

Lesica, P. \& Allendorf, F.W. (1995) When are peripheral populations valuable for conservation? Conservation Biology, 9, $753-760$.

López-GonzÁlez, C.A. (2004) Distribución, ecología y conservación del jaguar (Panthera onca) en el estado de Sonora. Oficio NUM/ SGPA/DGVS/03921, Escuela de Biología, Universidad Autónoma de Querétaro, Mexico.

Mahler, R. (2009) The Jaguar's Shadow: Searching for a Mythic Cat. Yale University Press, New Haven, USA.

Matthiessen, P. (1959) Wildlife in America. Viking Press, New York, USA.

Mattson, D., Hart, J., Miller, M. \& Miller, D. (2007) Predation and other behaviors of mountain lions in the Flagstaff Uplands. In Mountain Lions of the Flagstaff Uplands: 2003-2006 Progress Report (ed. D. Mattson), pp. 31-42. U.S. Geological Survey, Flagstaff, USA.

McCain, E.B. \& Childs, J.L. (2008) Evidence of resident jaguars (Panthera onca) in the southwestern United States and the implications for conservation. Journal of Mammology, 89, 1-10.

Menke, K.A. \& Hayes, C.L. (2003) Evaluation of the Relative Suitability of Potential Jaguar Habitat in New Mexico. Report to New Mexico Department of Game and Fish, Santa Fe, USA.

Navarro-Serment, C.J., López-González, C.A. \& GalloReynoso, J.P. (2005) Occurrence of jaguars (Panthera onca) in Sinaloa, Mexico. The Southwestern Naturalist, 50, 102-105.

Nielsen, J.L., Scott, J.M. \& Aycrigg, J.L. (2001) Endangered species and peripheral populations: cause for conservation. Endangered Species Update, 18, 193-220.

North American Atlas (2006) Ecological Regions of North America, Level III. Commission for Environmental Cooperation. Http://www3.cec.org/islandora/en/item/2560-ecological-regionsnorth-america-level-i-iii-en.pdf [accessed 10 May 2013].

Onorato, D., Belden, C., Cunningham, M., Land, D., McBride, R. \& Roelke, M. (2010) Long-term research on the Florida panther (Puma concolor coryi): historical findings and future obstacles to population persistence. In Biology and Conservation of Wild Felids (eds D.W. MacDonald \& A.J. Loveridge), pp. 453-469. Oxford University Press, Oxford, UK.

Povilitis, T. \& BeCKer, C.D. (2010) Advancing large carnivore recovery in the Southwest. In Southwestern Desert Resources (eds W.L. Halvorson, C.R. Schwalbe \& C. van Riper III), pp. 263-273. University of Arizona Press, Tucson, USA.

Rabinowitz, A. (1999) Present status of jaguars (Panthera onca) in the southwestern United States. The Southwestern Naturalist, 44, 96-100.

Rabinowitz, A. \& Zeller, K. (2010) A range-wide model of landscape connectivity and conservation for the jaguar, Panthera onca. Biological Conservation, 143, 939-945.

RAFINESQUE, C.S. (1832) On the Large Wanderings of Tygers or Jaguars of the United States. Atlantic Journal and Friend of Knowledge, Philadelphia, USA, pp. 18-19.

Redford, K.H., Amato, G., Baillie, J., Beldomencio, P., Bennet, E.L., Clum, N. et al. (2011) What does it mean to successfully conserve a (vertebrate) species? BioScience, 61, $39-48$.
Robinson, M.J. (2006) Habitat for Jaguar in New Mexico. Contract report to Arizona Game and Fish Department. Center for Biological Diversity, Silver City, USA.

Rosas-Rosas, O.C. (2006) Ecological status and conservation of jaguars (Panthera onca) in northeastern Sonora, Mexico. $\mathrm{PhD}$ thesis. New Mexico State University, Las Cruces, USA.

Sanderson, E.W., Redford, K.H., Chetriewicz, C.B., Medellin, R.A., Rabinowitz, A.R., Robinson, J.G. \& TABER, A.B. (2002) Planning to save a species: the jaguar as a model. Conservation Biology, 16, 58-72.

Seager, R., Mingfang, T., Held, I., Kushnir, Y., Lu, J., Vecchi, G. et al. (2007) Model projections of an imminent transition to a more arid climate in southwestern North America. Science, 316, 1181-1184.

Traill, L.W., Brook, B.W., Frankham, R.R. \& Bradshaw, C.J.A. (2010) Pragmatic population viability targets in a rapidly changing world. Biological Conservation, 143, 28-34.

USFWS (U.S. Fish and Wildlife Service) (2012a) Recovery Outline for the Jaguar. USFWS, Phoenix, USA.

USFWS (U.S. Fish and Wildlife Service) (2012b) Designation of critical habitat for jaguar, proposed rule. Federal Register, 77, 50213-50242.

USFWS (U.S. Fish and Wildlife Service) (2012c) Questions and Answers. Jaguar Critical Habitat Prudency Determination and Recovery Plan. Press release. Phoenix, USA.

USFWS (U.S. Fish and Wildlife Service) \& NMFS (National Marine Fisheries Service) (1996) Policy regarding the recognition of distinct vertebrate population segments under the Endangered Species Act. Federal Register, 61, 4722-4725.

USFWS (U.S. Fish \& Wildlife Service) \& NOAa (National Oceanic and Atmospheric Administration) (2011) Draft policy on interpretation of the phrase 'significant portion of its range' in the Endangered Species Act's definitions of 'Endangered Species' and 'Threatened Species'. Federal Register, 76, 76987-77006. VuCETiCh, J.A. \& W Aite, T.A. (2003) Spatial patterns of demography and genetic processes across the species' range: null hypothesis for landscape conservation genetics. Conservation Genetics, 4, 639-645.

Walston, J., Robinson, J.G., Bennett, E.L., Breitenmoser, U., Da Fonseca, G.A.B., Godrich, J. et al. (2010) Bringing the tiger back from the brink-the six percent solution. PLoS Biology, 8, e1000485.

WGA (Western Governors' Association) (2012) Initiative on Wildlife Corridors and Crucial Habitat. Http://www.westgov.org/ wildlife/ [accessed 2 June 2012].

WRP (Western Regional Partnership) (2013) Natural Resources Committee. Https://www.wrpinfo.org/Pages/Committees/

NaturalResources.aspx [accessed 10 May 2013].

Zeller, K. (2007) Jaguars in the New Millennium. Data Set Update: The State of the Jaguar in 2006. A report prepared for the Wildlife Conservation Society's Jaguar Conservation Program, Bronx, USA.

\section{Biographical sketch}

Tony Povilitis founded Life Net Nature, a non-profit organization devoted to community-based conservation, citizen science, and improved public policy toward wildlife. He pioneered studies of the Endangered huemul deer, leading to protected areas in Chile, was involved in the creation of a coral reef recovery team for Maui, Hawaii, and has developed international and U.S. field programmes for university students in conservation biology, natural resource management and wilderness education. 